\title{
The Psalm 103 Project: Orthodox Creative Musical Collaboration in Progress
}

\author{
RICHARD BARRETT*
}

The Psalm 103 Project is a major creative undertaking of The Saint John of Damascus Scoiety, a United States-based Orthodox sacred music nonprofit organization with the mission statement, "Revealing Orthodox Christianity through its sacred music." The project involves six very different composers, each a specialist in a different repertory of Orthodox music:

- Matthew Arndt, Assistant Professor of Music Theory at University of Iowa, is choir director at St. Raphael Antiochian Orthodox Church in Iowa City, IA and is a specialist in the sacred music of the Republic of Georgia and the Caucasus.

- John Michael Boyer, Director of Musical Activities at Holy Trinity Greek Orthodox Cathedral in Portland, OR and Protopsaltis of the Greek Orthodox Metropolis of San Francisco, is a seasoned cantor and composer in the modern received tradition of Byzantine chant, while also being experienced in the medieval Byzantine repertoire.

- Alexander Khalil is a cantor and composer who has studied the styles of Byzantine chant that are sung in Jerusalem and Constantinople; he also plays gamelan and is a researcher for the Temporal Dynamics of Learning Center at University of California Riverside.

- Kurt Sander is a composer, singer, and choral conductor in the Russian Orthodox Church Outside of Russia, having taught at Jordanville's Summer School of Liturgical Music for several years, and he is also Associate Professor of Theory and Composition in the Department of Music at Northern Kentucky University.

- Richard Toensing (+2014) was a composer of modern American art music who served on the faculty of University of Colorado at Boulder for many years, and whose Orthodox musical output represented a synthesis of Russian, Byzantine, and many other elements.

- TikeyZes, emeritus Theory and Composition faculty at San Jose State University, has been a pioneer of a Greek-American polyphonic style bringing together simpler melodic elements from Byzantine chant with a choral harmonic language informed as much by Western Renaissance music as by twentieth century American music.

* Richard Barrett, PhD Candidate at Indiana University. Address: 41 Cedrus Ave \#1, Boston, MA 02131 USA; e-mail: richardbarrett@johnofdamascus.org

RES 7 (3/2015), p. 472-475

DOI: $10.1515 /$ ress-2015-0036 
The six of them have been tasked with a unique challenge: collaborate on a long concert work in which each sets a section of the Vesperal Psalm in his own musical language, but still making it sound nonetheless like a single, cohesive piece of music.

The objective of this sacred musical collaboration is for the work to make a creative contribution from an Orthodox standpoint to the current science and faith discussion that is so prevalent in our society. The Society's board president, Harold Sabbagh, is at once a scientist and church musician who cares very deeply about such issues, and this effort is largely the result of his excitement over CERN's 2012 discovery of the Higgs boson. The psalm's text, which celebrates the divinely created order from the very small to the very large, was an ideal place to turn for inspiration, and the collaboration allows for a musical expression of the unity in diversity of the universe. Eventually, we seek to have the music serve as the basis for a film project that, while being a creative collaboration yet to be defined, is nonetheless intended at this point to be a cinematic meditation on science and faith from an Orthodox Christian perspective.

In October 2013, we brought our six composers to Bloomington, Indiana for a working weekend in which they were tasked with hammering out their collaborative approach and organizing principles. During that time, they agreed on the division of the text, they determined their organizational approach, and they had formulated thematic musical material that they would employ to keep the composition cohesive.After the weekend was over, everybody went home and started to compose.

In February 2014, Richard Toensingwas the first to turn in his completed sections. By the beginning of the summer, everybody had done enough that we had a large chunk of the work drafted, We hoped to meet again for a check-in and fine-tuning session; unfortunately, Richard Toensing's health took a turn for the worse, and while several of us were able to meet regardless, by the beginning of July, Richard had passed away.

I'd like to say a word about Richard's involvement, if I may: of the six collaborators, Richard was probably the most skeptical at the outset about the project's prospects. Nonetheless, he took the commission seriously and contributed to the fullest extent possible at all times. His influence can be seen across different layers of the work, and it can be truly said that it would not be what it has become without his participation. For example, his suggestions about how to approach the question of which English translation to use led to our consulting Archimandrite Ephrem (Lash), (official translator of the Greek Orthodox Archdiocese of Thyateira), and working with him as a group to craft a version of the text for Psalm 103 that would "sing" the way we needed. 
In addition, as it turned out, Matthew Arndt had been a Masters student of Richard's at UC Boulder.

The music that Richard wrote for us is also nothing short of a gift; by itself it is a masterwork for the Anglophone Orthodox world. We told everybody during the working weekend, "Swing for the fences. Write for the strengths of the best choir you can imagine." All of them did this in one way or another, but when I opened Richard's score and saw antiphonal 8 voice choirs, I understood just how seriously he had taken me. The MIDI file is absolutely stunning; I can't wait for everybody to hear it sung.

To take a moment to discuss the collaborative process itself: during our working weekend, Kurt Sander characterized the challenge as everyone needing to build part of the same house without knowing for certain what the house was going to look like. The six of them approached the problem by first dividing up the text, and then agreeing to some general structural points, unifying musical material, and approaches for handling the transitions. After everybody went home, they consulted each other as needed. When part of the group met up in Cincinnati in June of 2014, Matthew and Kurt did some catching up in person; Matthew wanted to see if, working together, they could improve the pivot from Kurt's material to Matthew's. He wrote out a couple of possibilities, showed them to Kurt, Kurt tinkered with them on his own for a bit, and then they agreed on a solution together, which Kurt then incorporated into the end of his score. As Kurt said to me later, "It's definitely better."

By June of this year, we had a completed score, which I presented at the conference of the International Society for Orthodox Church Music in Joensuu, Finland. We had successfully hit our first milestone.

So now what? Well, we have a number of tasks in front of us yet. MusicaRussica is going to publish the score, and Vladimir Morosan is presently working on taking all of the raw Finale and Sibelius files and turning them into commercial-quality engraved music.

We are also working hard to plan the premiere performances and recording of the work. The Saint John of Damascus Society and Cappella Romana have an agreement that, funding permitting, Cappella will premiere the piece as part of their 2016/2017 concert season, and record it shortly thereafter. The CD will be released commercially, if all goes well, by Christmas 2017 .

Within that timeframe we intend to start talking to filmmakers about the possibilities for the cinematic phase. As we did with the composers, we will treat this as a creative collaboration, and I for one am very interested to hear what will be proposed. As somebody born in 1976, Carl Sagan's original Cosmos TV series has always been my point of reference for this phase; he did an unforgettable job of juxtaposing images of galaxies and stars and 
animals and plants and DNA with masterpieces of Western classical music, and even contemporary experimental music like Vangelis. Perhaps our filmmaker will come up with something similar; perhaps our filmmaker will come up with something completely different.

At present one of our other major priorities is also fundraising and building of public awareness. We have received lead support from Carol Toensing, Richard Toensing's wife, as well as the National Forum of Greek Orthodox Church Musicians; we are cultivating gifts and grants from other individuals and foundations as well.

The goal of The Psalm 103 Project is to inspire and engage a public audience by celebrating creation through creativity and tradition, and employing the diverse beauty of the music of Orthodox Christianity as a way to reflect and celebrate the great variety of God's universe. I encourage you to look around on the project's website (http://www.thepsalm103project.org), where you will find composer bios, a reflection on Richard Toensing's involvement, a truly generous endorsement by Fr. Ivan Moody, a preview gallery of the score, and more. It is my hope that you will find the efforts of our collaborators on this project to be at once a blessing and an inspiration, and I look forward to sharing more as things develop. 